\title{
Copy number variation and susceptibility to human disorders (Review)
}

\author{
BARKUR S. SHASTRY \\ Department of Biological Sciences, Oakland University, Rochester, MI, USA
}

Received October 6, 2008; Accepted November 26, 2008

DOI: $10.3892 / \mathrm{mmr} 00000074$

\begin{abstract}
A large number of analyses of a new form of genetic variation, known as copy number variation $(\mathrm{CNV})$, have been published recently as a new tool for understanding the genetic basis of complex traits such as diabetes, asthma, Crohn's disease, autism and bipolar disorder. Through the use of different types of genome-wide scanning procedures, CNVs have been shown to be associated with several complex and common disorders, including nervous system disorders. One of the common features of the regions associated with the complex and common disorders identified thus far is the presence of CNVs and segmental duplications. Segmental duplications lead to genome instability. Because of their location and nature (several contain genes), many CNVs have functional consequences, such as gene dosage alteration, the disruption of genes and the modulation of the activities of other genes. Therefore, these genetic variations have an influence on phenotypes, the susceptibility of an individual to disease, drug response and human genome evolution. These types of variants (gain and loss of DNA) are not restricted to humans, having also been identified in other organisms. Our current knowledge regarding $\mathrm{CNVs}$ and their heritability is still rudimentary, due to their location in regions of complex genomic structure and to the technical limitations of association studies. Future advances in the technology will aid in the construction of a new CNV map, used to find the genes underlying common diseases and to understand familial genetic conditions, severe developmental defects in humans and other organisms, and genome evolution.
\end{abstract}

\section{Contents}

1. Introduction

2. Properties and functions

3. Technical developments and limitations

4. Summary and conclusion

Correspondence to: Dr Barkur S. Shastry, Department of Biological Sciences, Oakland University, Rochester, MI, USA E-mail: shastry@oakland.edu

Key words: arrays, duplication, deletion, gene, mutation, polymorphism

\section{Introduction}

Structural chromosome abnormalities have for a long time been known to exist at the cytogenetic and molecular level, and are associated with what are now called genome disorders. However, their importance became apparent only after the completion of the human genome project due to the use of several scanning technologies, including array-based comparative genomic hybridization (CGH). DNA, the genetic material, varies widely from person to person (1) and between human populations worldwide (2). Some individuals have variation in a single nucleotide, which is known as a single nucleotide polymorphism (SNP). The term polymorphism generally refers to genetic variants that have a minor allelic frequency $(\sim 1 \%)$ in a given population. These changes are thought to be the predominant form of the genetic variations responsible for normal phenotypic differences (our uniqueness). However, it has recently been discovered that there are individuals with deletions or multiple copies of the same gene (Fig. 1). Such changes (DNA fragments of $\sim 1 \mathrm{~kb}$ or larger) are called copy number variations (CNVs) or copy number polymorphisms (3-5), and additionally appear to be widespread in normal individuals. Although the true number of CNVs and their frequency in human populations is unknown, they may result in altered levels of gene expression and, as a result, may account for significant normal phenotypic variation within a species (as they often encompass genes), susceptibility or resistance to disease, drug response, complex and common disorders and the evolution of the genome itself (6-13). This brief review summarizes some of the recent research in the field of CNVs.

\section{Properties and functions}

The size of DNA variation in CNVs ranges from a few kilobases to megabases (14-16). CNVs are not necessarily related to genome disorders, and can in fact be observed in healthy individuals who present no evidence of a genetic disorder (17). At present, approximately $1447 \mathrm{CNV}$ s have been identified (http://projects.tcag.ca/variation). These cover $12 \%$ (of an estimated $15 \%$ ) of the human genome, although this number could be slightly smaller for common human CNVs (18). Additionally, somatic mosaicism has been reported for CNVs in differentiated human tissue (19). This high degree of variability in the human genome and somatic mosaicism challenges the definition of normality (20), since it is generally 

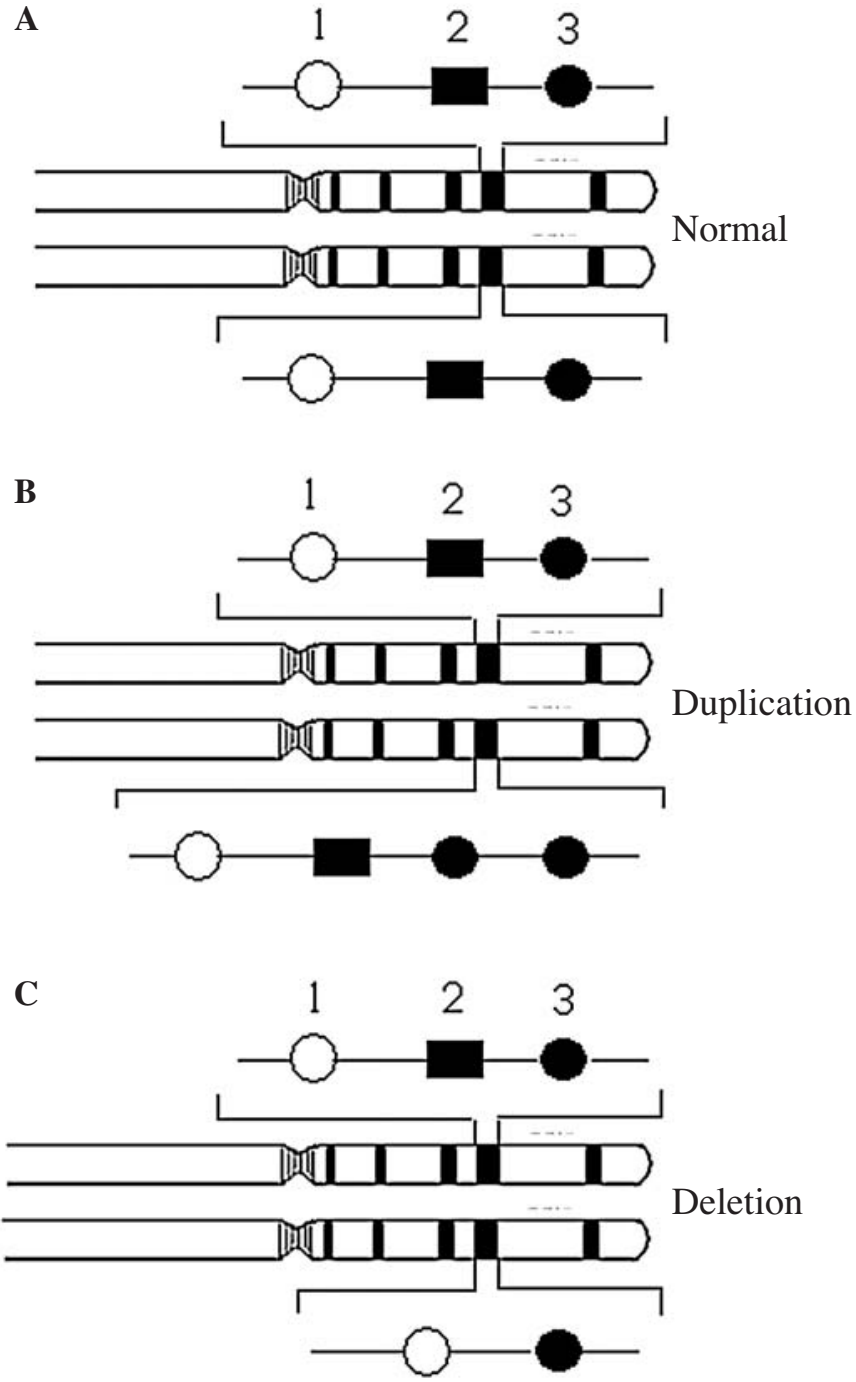

Figure 1. An example of CNV. A represents a normal pattern, while B (duplication) and $\mathrm{C}$ (deletion) are CNVs. Numbers 1,2 and 3 represent genes in a chromosomal segment.

believed that normal cells are genetically identical. Large $\mathrm{CNVs}$ are often found to occur in regions containing large homologous repeats or segmental duplication $(15,21,22)$, while smaller CNVs may occur because of non-homology driven mutational mechanisms. A DNA replication-based mechanism has been suggested to explain the formation of CNVs (23). According to this mechanism, the presence of many nucleotide repeats (which form an unusual structure) stalls the replication fork and then switches to a different template in any region of DNA, resulting in copy number changes. This kind of stalling and template switching may play a role in evolution by helping organisms to survive under environmental stress. Widespread CNVs are not unique to humans; they have also been identified in inbred strains of laboratory mice $(24,25)$. In these mice, a non-allelic homologous recombination mechanism may play a role in the genesis of CNVs (26). CNVs, along with SNPs, also contribute to phenotypic variation among mouse strains. In addition, different mouse strains exhibit CNVs that are comparable to those observed in human strains. However, such variation is more locally restricted $(27,28)$.
From an evolutionary standpoint, gene duplication is an important long-term evolutionary force (e.g., the B-globulin gene). Supporting this is the finding that CNVs are present in the homologous regions of other closely-related species (27). This again suggests that non-allelic homologous recombination plays a role in the evolution of CNV. Interestingly, mice seem to tolerate large-scale deletions of non-gene regions much better than humans (29). When human and mouse CNVs were compared, it was found that those of humans were associated with an increased ratio of non-synonymous to synonymous substitution rates (30), suggestive of positive selection during evolution. Similarly, when the CNV regions of chimpanzees and humans were compared, many CNVs were found to occur frequently in both species, and were also found to be rich in segmental duplication. This finding is consistent with the hypothesis that CNVs are found in the homologous regions of other closely-related species (27). Furthermore, lineage-specific gene duplication and loss may occur during evolution (31-33). Analysis of structural variation in eight human genomes additionally suggests that different mutational processes may have shaped the human genome (34). It has been demonstrated, at least in the case of the Drosophila system, that natural selection shapes the genomewide patterns of CNV $(35,36)$. Since segmental duplications lead to genomic instability, they are not only associated with genome disorders, but are also involved in the continuing evolution of the genome.

CNVs may alter gene dosage without abolishing gene function, or may affect gene structure and regulation (37). Because of their mild effect on gene function, it is possible that some of the common CNVs alter phenotypes in complex and sporadic diseases (38), including nervous system disorders $(39,40)$, and may also be behind inherited disorders (41). For instance, in non-small cell lung cancer, the EGFR copy number is found to be higher than normal (6). Additionally, individual and population differences in copy number for the gene encoding CCL3L1 (a suppressive chemokine and ligand for the human immunodeficiency virus-1 coreceptor CCR5) have been reported (7). Similarly, a lower copy number of FCGR3B can increase susceptibility to immunologicallyrelated glomerulonephritis in humans and rats (8), with a functional correlation between $\mathrm{CNV}$ and protein expression (42). Copy number variation is also found to be associated with autism spectrum disorders $(9,13)$, Crohn's disease (43) and bipolar disorder (44). A partial list of some of the other disease-related chromosomal regions containing CNVs is presented in Table I. However, the extent to which CNVs cause genetic disease is unclear. According to the literature, their contribution appears to be smaller than that of SNPs (37), and their contribution to gene expression is also independent of SNPs.

\section{Technical developments and limitations}

At present, it is difficult to correlate the relationship between CNVs and phenotype. This is due to insufficient collected data, and existing techniques that are not accurate enough in measuring the association between CNVs and phenotype. As well, many CNVs are located in regions of complex genomic structure. An effective genome-wide CNV genotyping method 
Table I. Examples of CNVs identified in genomic regions associated with disease ${ }^{\text {a }}$.

\begin{tabular}{lcc}
\hline Disorders & Chromosomal regions & Refs. \\
\hline Bipolar & $3 q 13.3$ & $(44)$ \\
Spinal muscular atrophy & $5 \mathrm{q} 13.2$ & $(14,15,21)$ \\
Crohn's disease & $8 \mathrm{p} 23.1$ & $(43)$ \\
Prader-Willi and Angelman syndrome & $15 \mathrm{q} 11.3$ & $(13), 15)$ \\
Autism & $16 \mathrm{p} 11.2$ & $(4,21)$ \\
Charcot-Marie-tooth Angelman syndrome & $17 \mathrm{p} 12$ & $(9)$ \\
Autism & $20 \mathrm{p} 13$ & $(4,5,21,58)$ \\
DiGeorge/Velocardiofacial syndrome & $22 \mathrm{q} 11.2$ & \\
\hline
\end{tabular}

In some cases, these CNVs are also present in normal individuals.

is required. As was recently demonstrated, one possible approach is to use SNPs as markers for CNVs throughout the genome by means of the linkage disequilibrium (LD) method. This approach relies on the low recombination rate found in humans. Variants segregate on the haplotype and can hence be tagged (45). However, the method still requires a large collection of CNVs with dense SNP genotypes. Additionally, since many CNVs are located in regions of complex genomic structure, it may limit the extent to which these variants can be genotyped using tagging SNPs. Although there have been some successes in recent years $(3,4,10,46)$, with certain of the CNVs within the duplicated regions showing LD with nearby SNPs $(21,46,47)$ and a heritability value that did not significantly differ among the loci tested, the extent of LD between SNPs and CNVs is not at present clear (48). For instance, a region of the genome may contain high-density CNVs (21), but the density of SNPs that serve as potential tags could be much lower. The high-density CNVs may therefore not be well tagged by the SNPs (46). Markers also determine whether to focus on common polymorphisms that principally affect phenotype, or on the markers which have modifying effects on other genes or environmental factors (49). Additionally, non-Mendelian behavior may pose a problem in the use of SNPs for tagging the inheritance of CNVs.

Another equally important technical development are hybrid oligonucleotide arrays containing both SNPs and copy number probes. In this method, SNPs and CNVs are used together for association studies $(50,51)$. Recently, microarray $\mathrm{CGH}$ has also been used. This method detects differences in CNVs across diverse species (27), and also assesses CNVs at multiple loci. Additionally, CNVs can be determined using oligonucleotide expression microarrays (52), bacterial artificial chromosome (BAC) arrays (17), SNP arrays and genotyping data. A review concerning the different genotyping platforms available was recently published (53). In addition, there are a variety of fine mapping techniques that researchers use to test for disease association $(7,8,54,55)$ using a family-based (traditional) or population-based model. These methods are effective when CNVs are large, as such variations are usually taken as functional and hence causative. However, smaller CNVs that are mostly benign and can therefore not be determined as functional require statistical challenges to assess their association with diseases. Similarly, other limitations, such as insufficient recombination events, the requirement of a large pedigree, low penetrance and population stratification, must be considered in determining CNV and SNP association. Some of the methods may not be able to detect the lowpenetrant variants associated with common diseases. Familybased studies are the easiest way to prevent stratification, and are therefore preferred by many investigators (49). Additionally, the quality of DNA and the sensitivity of methods such as CGH may introduce technical artifacts in association studies (56). The maintenance of high standards throughout the research process is therefore a necessity.

\section{Summary and conclusion}

In summary, by using array CGH and high-density customized nucleotide arrays, several regions of chromosomes containing CNVs have been identified. Research in the CNV field also suggests that large-scale variation in the human genome could be due to segmental duplications. These lead to genome instability and are hence associated with genome disorders, as well as with the evolution of the genome. They are also the hotspots of chromosomal rearrangement (17). However, our understanding of their organization and heritability is still in its infancy. Although there are many technical advances to be made in the future, the long-term goal of CNV research is to prepare a comprehensive CNV map of the human genome. This includes the correlation of variation to phenotypes and to evolutionary and mutational aspects. Since CGH and highdensity oligonucleotide arrays $(47,57)$ are cost effective and rapid, they are at present the most valuable tools for CNV research. As in many other experiments, numerous artifacts or false-positives will be encountered in CNV research. These must be minimized. In addition, high priority should be given to validation. A suitable scanning technology must be developed. When new technologies become available, primary results must be verified. Although the field is technically challenging and very expensive to accommodate within the limited amount of available resources, in the coming years it is hoped that CNV research will not only provide insight into human genetic variation, but will also contribute to a better understanding of the mechanisms of human genetic disease and evolution. 


\section{Acknowledgements}

My apologies to those whose work or original publications could not be cited in this short article because of limitations to the number of references.

\section{References}

1. Khaja R, Zhang J, MacDonald JR, He Y, Joseph-George AM, Wei J, Rafiq MA, Qian C, Shago M, Pantano L, Aburatani H, Jones K, Reddon R, Hurles M, Armengol L, Estivill X, Mural RJ, Lee C, Scherer SW and Feuk L: Genome assembly comparison identifies structural variants in the human genome. Nat Genet 38 : 1413-1418, 2006.

2. Jakobsson M, Scholz SW, Scheet P, Gibbs JR, VanLiere JM, Fung HC, Szpiech ZA, Degnan JH, Wang K, Guerreiro R, Brass JM, Schymick JC, Hernandez DG, Tyarnor BJ, SimonSanchez J, Matarin M, Britton A, van de Leemput J, Rafferty I, Bucan M, Cann HM, Hardy JA, Rosenberg NA and Singleton AR: Genotype, haplotype and copy number variation in world wide human populations. Nature 451: 998-1003, 2000.

3. Hind DA, Kloek AP, Jen M, Chen X and Frazer KA: Common deletions and SNPs are in linkage disequilibrium in the human genome. Nat Genet 38: 82-85, 2006.

4. McCarroll SA, Hadnott TN, Perry GH, Sabeti PC, Zody MC, Barrett JC, Dallaire S, Gabriel SB, Lee C, Daly MJ and Altshuler DM: Common deletion polymorphisms in the human genome. Nat Genet 38: 86-92, 2006.

5. Conard DF, Andrews TD, Carter NP, Hurles ME and Pritchard JK: A high-resolution survey of deletion polymorphism in the human genome. Nat Genet 38: 75-81, 2006.

6. Cappuzzo F, Hirsch FR, Rossi E, Bartolini S, Ceresoli GL, Bemis L, Haney J, Witta S, Danenberg K, Domenichini I, Ludovini V, Magrini E, Gregorc V, Doglioni C, Sidoni A, Tanato M, Franklin WA, Crino L, Bunn PA Jr and VareliaGarcia M: Epidermal growth factor receptor gene and protein and gefitinib sensitivity in non-small-cell lung cancer. J Natl Cancer Inst 97: 643-655, 2005.

7. Gonzalez E, Kulkarni H, Bolivar H, Mangano A, Sanchez R, Catano G, Nibbs RJ, Freedman BI, Quinones MP, Bamshad MJ, Murthy KK, Rovin BH, Bradley W, Clark RA, Anderson SA, O'Connell RJ, Agan BK, Ahuja SS, Bologna R, Sen L, Dolan MJ and Ahuja SK: The influence of CCL3L1 gene-containing segmental duplication on HIV-1/AID susceptibility. Science 307 : 1434-1440, 2005.

8. Aitman TJ, Dong R, Vyse TJ, Norsworthy PJ, Johnson MD, Smith J, Mangion J, Roberton-Lowe C, Marshall AJ, Petretto E, Hodges MD, Bhangal G, Patel SG, Sheehan-Rooney K, Duda M, Cook PR, Evans DJ, Domin J, Flint J, Boyle JJ, Pusey CD and Cook HT: Copy number polymorphism in Fcgr 3 predisposes to glomerulonephritis in rats and humans. Nature 439: 851-855, 2006.

9. Sebat J, Lakshmi B, Malhotra D, Troge J, Lese-Martin C, Walsh T, Yamrom B, Yoon S, Krasnitz A, Kendall J, Leotta A, Pai D, Zhang R, Lee Y-H, Hicks J, Spence SJ, Lee AT, Puura K, Lehtimaki T, Ledbetter D, Gregersen PK, Bregman J, Sutcliffe JS, Jobanputra V, Chung W, Warburton D, King M-C, Skuse D, Geschwind DH, Gilliam TC, Ye K and Wigler M: Strong association of de novo copy number mutations with autism. Science 316: 445-449, 2007.

10. Reddon R, Ishikawa S, Fitch KR, Feuk L, Perry GH, Andrews TD, Fiegler H, Shapero MH, Carson AR, Chen W, Cho EK, Dallaire S, Freeman JL, Gonzalez JR, Gratacos M, Huang J, Kalaitzopoulos D, Komura D, MacDonald JR, Marshall CR, Mei R, Montgomery L, Nishimura K, Okamura K, Shen F, Somerville MJ, Tchinda J, Valsesia A, Woodwark C, Yang F, Zhang J, Zerjal T, Zhang J, Armengol L, Conard DF, Estivill X, Tyler-Smith C, Carter NP, Aburatani H, Lee C, Jones KW, Schere SW and Hurles ME: Global variation in copy number in the human genome. Nature 444: 444-454, 2006.

11. McCarroll SA and Altshuler DM: Copy number variation and association studies of human disease. Nat Genet 39: S37-S42, 2007.

12. Freeman JL, Perry GH, Feuk L, Reddon R, McCarroll SA, Altshuler DM, Aburatani H, Jones KW, Tyler-Smith C, Hurles ME, Carter NP, Scherer SW and Lee C: Copy number variation: new insight in genome diversity. Genome Res 16: 949-961 2006.
13. Marshall CR, Noor A, Vincent JB, Lionel AC, Feuk L, Skaug J, Shago M, Moessner R, Pinto D, Ren Y, Thiruvahindrapduram B, Fiebig A, Schrelber S, Friedman J, Ketelaars CE, Vos YJ, Ficicioglu C, Kirkpatrick S, Nicolson R, Sloman L, Summers A, Gibbons CA, Teebi A, Chitayat D, Weksberg R, Thompson A, Vardy C, Crosbie V, Luscombe S, Baatjes R, Zwaigenbaum L, Roberts W, Fernandez B, Szatmari P and Scherer SW: Structural variation of chromosomes in autism spectrum disorder. Am J Hum Genet 82: 477-488, 2008.

14. Sebat J, Lakshmi B, Troge J, Alexander J, Young J, Lundin P, Maner S, Massa H, Walker M, Chi M, Navin N, Lucito R, Healy J, Hicks J, Ye K, Reiner A, Gilliam TC, Trask B, Patterson N, Zetterberg A and Wigler M: Large scale copy number polymorphism in the human genome. Science 305: 525-528, 2004.

15. Iafrate AJ, Feuk L, Rivera MN, Listewnik ML, Donahoe PK, Qi Y, Scherer SW and Lee C: Detection of large scale variation in the human genome. Nat Genet 36: 941-951, 2004.

16. Buckland PR: Polymorphically duplicated genes: their relevance to phenotypic variation in humans. Ann Med 35: 308-315, 2003.

17. De Stahl TD, Sandgren J, Piotrowski A, Nord H, Andersson R, Menzel U, Bogdan A, Thuresson AC, Poplawski A, von Tell D, Hansson CM, Elshafie AI, Elghazali G, Imreh S, Nordenskjold M, Upadhyaya M, Komorowski J, Bruder CE and Dumanski JP: Profiling of copy number variations (CNVs) in healthy individuals from three ethnic groups using a human genome $32 \mathrm{KBAC}-$ cloned-base array. Hum Mutat 29: 398-408, 2008.

18. Perry GH, Ben-Dor A, Tsalenko A, Sampas N, RodriguezRevenga L, Tran CW, Scheffer A, Steinfeld I, Tsang P, Yamada NA, Park HS, Kim JI, Seo JS, Yakhini Z, Laderman S, Bruhn L and Lee C: The fine scale and complex architecture of human copy number variation. Am J Hum Genet 82: 685-695, 2008.

19. Piotrowski A, Bruder CE, Andersson R, De Stahl TD, Menzel U, Sandgren J, Poplawski A, von Tell D, Crasto C, Bogdan A, Bartoszewski R, Bebok Z, Krzyzanowski M, Jankowski Z, Partridge EC, Komorowski J and Dumanski JP: Somatic mosaicism for copy number variation in differentiated human tissues. Hum Mutat 29:1118-1124, 2008.

20. Kehrer-Sawatzki H: What a difference copy number variation makes. BioEssays 29: 311-313, 2007.

21. Sharp AJ, Locke DP, McGrath SD, Cheng Z, Bailey JA, Vallente RU, Pertz LM, Clark RA, Schwartz S, Segraves R, Oseroff VV, Albertson DG, Pinkel D and Eichler EE: Segmental duplication and copy number variation in the human genome. Am J Hum Genet 77: 78-88, 2005.

22. Tuzun E, Sharp AJ, Bailey JA, Kaul R, Morrison VA, Pertz LM, Haugen E, Hayden H, Albertson D, Pinkel D, Olson MV and Eichler EE: Fine-scale structural variation of the human genome. Nat Genet 37: 727-732, 2005.

23. Lee JA, Carvalho CM and Lupski JR: A DNA replication mechanism for generating nonrecurrent rearrangements associated with genomic disorders. Cell 131: 1235-1247, 2007.

24. Li J, Jiang T, Mao JH, Balmain A, Peterson L, Harris C, Rao PH, Havlak P, Gibbs R and Cai WW: Genomic segmental polymorphisms in inbred mouse strains. Nat Genet 36: 952-954, 2004.

25. Adams DJ, Dermitzakis ET, Cox T, Smith J, Davies R, Banerjee R, Bonfield J, Mullikin JC, Chung YJ, Rogers J and Bradely A: Complex haplotypes, copy number polymorphisms and coding variation in two recently divergent mouse strains. Nat Genet 37: 532-536, 2005.

26. Lupski JR: Genomic disorders: structural features of the genome can lead to DNA rearrangements and human disease traits. Trends Genet 14: 417-422, 1998.

27. Perry GH, Tchinda J, McGrath SD, Zhang J, Picker SR, Caceres AM, Iafrate AJ, Tyler-Smith C, Scherer SW, Eichler EE, Stone AC and Lee C: Hotspots for copy number variation in chimpanzees and humans. Proc Nat Acad Sci USA 103: 8006-8011, 2006.

28. She X, Cheng Z, Zollner S, Church DM and Eichler EE: Mouse segment duplication and copy number variation. Nat Genet 40: 909-914, 2008.

29. Nobrega MA, Zhu Y, Plajzer-Frick I, Afzal V and Rubin EM: Megabase deletions of gene deserts result in viable mice. Nature 431: 988-993, 2004.

30. Nguyen DQ, Webber C and Ponting CP: Basis of selection on human copy number variants. PLoS Genet 2: 198-207, 2006.

31. Fortna A, Kim Y, MacLaren E, Marshall K, Hahan G, Meltesen L, Brenton M, Hink R, Burgers S, Hernandez-Boussard T, Karimpour-Fard A, Glueck D, McGavran L, Berry R, Pollack J and Sikela JM: Lineage-specific gene duplication and loss in human and great ape evolution. PLoS Biol 2: E207-E222, 2004. 
32. Cheng Z, Ventura M, She X, Khaitovich P, Graves T, Osoegawa K, Church D, DeJong P, Wilson RK, Paabo S, Rocchi M and Eichler EE: A genome-wide comparison of recent chimpanzee and human segmental duplications. Nature 43 : 788-793, 2005.

33. Newman TL, Tuzun E, Morrison VA, Hayden KE, Ventura M, McGrath SD, Rocchi M and Eichler EE: A genome-wide survey of structural variation between human and chimpanzee. Genome Res 15: 1344-1356, 2005.

34. Kid JM, Cooper GM, Donahue WF, Hayden HS, Sampas N, Graves T, Hansen N, Teague B, Alkan C, Antonacci F, Haugen E, Zerr T, Yamada NA, Tsang P, Newman TL, Tuzun E, Cheng Z, Ebling HM, Tusneem N, David R, Gillett W, Phelps KA, Weaver M, Saranga D, Brand A, Tao W, Gustafson E, McKernan K, Chen L, Malig M, Smith JD, Korn JM, McCarroll SA, Altshuler DA, Peiffer DA, Dorschner M, Stamatoyannopoulos J, Schwartz D, Nickerson DA, Mullikin JC, Wilson RK, Bruhn L, Olson MV, Kaul R, Smith DR and Eichler EE: Mapping and sequencing of structural variation from eight human genomes. Nature 453: 56-64, 2008

35. Emerson JJ, Cardoso-Moreira M, Borevitz JO and Long M: Natural selection shapes genome wide patterns of copy number polymorphism in Drosophila melanogaster. Science 320: 1629-1631, 2008.

36. Dopman EB and Hartl DL: A portrait of copy number polymorphism in Drosophila melanogaster. Proc Nat Acad Sci USA 104. 19920-19925, 2007.

37. Stranger BE, Forrest MS, Dunning M, Ingle CE, Beazley C, Thome N, Reddon R, Bird CP, De Grassi A, Lee C, TylerSmith C, Scherer SW, Tavare S, Deloukas P, Hurles ME and Dermitzakis ET: Relative impact of nucleotide and copy number variation on gene expression phenotypes. Science 315: 848-853, 2007.

38. Inoue $\mathrm{K}$ and Lupski JR: Molecular mechanisms for genomic disorders. Ann Rev Genomics Hum Genet 3: 199-242, 2002.

39. Lee JA and Lupski JR: Genomic rearrangements and copy number alterations as a cause of nervous system disorders. Neuron 52: 103-121, 2006.

40. Esch HV, Bauters M, Ignatius J, Jansen M, Raynaud M, Hollanders K, Lugtenberg D, Bienvenu T, Jensen LR, Gecz J, Moraine C, Marynen P, Fryns J-P and Froyen G: Duplication of the MECP2 region is a frequent cause of severe mental retardation and progressive neurological symptoms in males. Am J Hum Genet 77: 442-453, 2005 .

41. Lupski JR: Genomic rearrangements and sporadic disease. Nat Genet 39: S43-S47, 2007.

42. Willcocks LC, Lyons PA, Clatworthy MR, Robinson JI, Yang W, Newland SA, Plagnol V, McGovern NN, Condliffe AM, Chilvers ER, Adu D, Jolly EC, Watts R, Lau YL, Morgan AW, Nash G and Smith KG: Copy number of FCGR3B, which is associated with systemic lupus erythematosus, correlates with protein expression and immune complex uptake. J Exp Med 205: $1575-1582,2008$.

43. Fellermann K, Stange DE, Shaeffeler E, Schmalzl H, Wehkamp J, Bevins CL, Reinisch W, Teml A, Schwab M, Lichter P, Radlwimmer B and Stange EF: A chromosome 8 gene cluster polymorphism with low human beta-defensin 2 gene copy number predisposes to Crohn disease of the colon. Am J Hum Genet 79: 439-448, 2006

44. Lachman HM, Perdosa E, Petruolo OA, Cockerham M, Papolos A, Novak T, Papolos DF and Stopkova P: Increase in GSK3 beta gene copy number variation in bipolar disorder. Am J Med Genet B Neuropsychiatr Genet 144B: 259-265, 2007

45. Gabriel SB, Scaffner SF, Nguyen H, Moore JM, Roy J, Blumenstiel B, Higgins J, DeFelice M, Lochner A, Faggart M, Liu-Cordero SN, Rotimi C, Adeyemo A, Cooper R, Ward R Lander ES, Daly MJ and Altshuler D: The structure of haploid blocks in the human genome. Science 296: 2225-2229, 2002.
46. Locke DP, Sharp AJ, McCarroll SA, McGrath SD, Newman TL Cheng Z, Schwartz S, Albertson DG, Pinkel D, Altshuler DM and Eichler EE: Linkage disequilibrium and heritability of copy number polymorphisms within duplicated regions of the human genome. Am J Hum Genet 79: 275-290, 2006.

47. Komura D, Shen F, Ishikawa S, Fitch KR, Chen W, Zhang J, Liu G, Ihara S, Nakamura H, Hurles ME, Lee C, Scherer SW, Jones KW, Shapero MH, Huang J and Aburatani H: Genome wide deletion of human copy number variations using high-density DNA oligonucleotide arrays. Genomic Res 16: 1575-1584, 2006.

48. Estivill X and Armengol L: Copy number variants and common disorders: filling the gap and exploring complexity in genome wide association studies. PLoS Genetics 3: e190-e203, 2007.

49. Thomas DC, Haile RW and Duggan D: Recent developments in genome-wide association scan: a workshop summary and review. Am J Hum Genet 77: 337-345, 2005.

50. Zhao X, Li C, Paez JG, Chin K, Janne PA, Chen TH, Girard L, Minna J, Christiani D, Leo C, Gray JW, Sellers WR and Meyerson M: An integrated view of copy number and allelic alterations in the cancer genome using single oligonucleotide polymorphism arrays. Cancer Res 64: 3060-3071, 2004.

51. Franke L, De Kovel CG, Aulchenko YS, Trynka G, Zhernakova A, Hunt KA, Blauw HM, van den Berg LH, Ophoff R, Deloukas P, van Heel DA and Wijmenga C: Deletion, imputation and association analysis of small deletions and null alleles on oligonucleotide arrays. Am J Hum Genet 82: 1316-1333, 2008.

52. Auer H, Newsom DL, Nowak NJ, McHugh KM, Sunita S, Yu C-Y, Yang Y, Wenger GD, Gastier-Foster JM and Kornacker KL: Gene resolution analysis of DNA copy number variation using oligonucleotide expression microarrays. BMC Genomics 8: 111-117, 2007.

53. Carter NP: Methods and strategies for analyzing copy number variation using DNA microarrays. Nat Genet 39: S16-S21, 2007.

54. Yang Y, Chung EK, Wu YL, Savelli SL, Nagaraja HN, Zhou B, Hebert M, Jones KN, Shu Y, Kitzmiller K, Bianchong CA, McBride KL, Higgins GC, Rennebohm RM, Rice RR, Hackshaw KV, Roubey RA, Grossman JM, Tsao BP, Birmingham DJ, Rovin BH, Hebert LA and Yu CY: Gene copy number variation and associated polymorphisms of complement component $\mathrm{C} 4$ in human systemic lupus erythematosus (SLE): low copy number is a risk factor for and high copy number is a protective factor against SLE susceptibility in European Americans. Am J Hum Genet 80: 1037-1054, 2007.

55. Fanciulli M, Norsworthy PJ, Petretto E, Dong R, Harper L, Kamesh L, Heward JM, Gough SC, De Smith A, Blakemore AI, Froguel P, Owen CJ, Pearce SH, Teixeira L, Guillevin L, Graham DS, Pusey CD, Cook HT, Vyse TJ and Aitman TJ: FCGR3B copy number variation is associated with susceptibility to systemic but not organ-specific autoimmunity. Nat Genet 39: 721-723, 2007.

56. Fiegler H, Reddon R, Andrews D, Scott C, Andrews R, Carder C, Clark R, Dovey O, Ellis P, Feuk L, French L, Hunt P, Kalaitzopoulos D, Larkin J, Montgomery L, Perry GH, Plumb BW, Porter K, Rigby RE, Rigler D, Valsesia A, Langford C, Humphray SJ, Scherer SW, Lee C, Hurles ME and Carter NP: Accurate and reliable high-throughput detection of copy number variation in the human genome. Genome Res 16: 1566-1574, 2006.

57. Dhami P, Coffey AJ, Abbs S, Vermeesch JR, Dumanski JP, Woodward KJ, Andrews RM, Langford C and Vetrie D: Exon array CGH: detection of copy number changes at the resolution of individual exons in the human genome. Am J Hum Genet 76: 750-762, 2005.

58. Babcock M, Yatsenko S, Hopkins J, Brenton M, Cao Q, De Jong P Stankiewicz P, Lupski JR, Sikela JM and Morrow BE: Hominoid lineage specific amplification of low copy repeats on 22q11.2 (LCR22s) associated with velo-cardo-facial/digeorge syndrome. Hum Mol Genet 16: 2560-2571, 2007. 